\title{
Belang van ondersteunende netwerken voor ouderen
}

H.M. van Dijk MSc, dr. J.M. Cramm, dr. M. Goumans, ${ }^{3}$ drs. A. Brix, S. Bakker MHA ${ }^{5}$ en prof. dr. A.P. Nieboer

${ }^{7}$ promovendus instituut Beleid \& Management Gezondheidszorg (iBMG), Erasmus Universiteit Rotterdam (EUR)

${ }^{2}$ universitair docent instituut Beleid \& Management Gezondheidszorg (iBMG), Erasmus Universiteit Rotterdam (EUR)

${ }^{3}$ voorzitter werkgroep scholing Even Buurten, lector Samenhang in de ouderenzorg, Hogeschool Rotterdam

${ }^{4}$ projectleider Even Buurten en senior adviseur RadarAdvies

${ }^{5}$ penvoerder Even Buurten en programmamanager Woonservicegebieden, Gemeente Rotterdam, Directie Activering en Welzijn, Cluster Maatschappelijke Ontwikkeling

${ }^{6}$ projectleider evaluatie Even Buurten en hoogleraar sociaal-medische wetenschappen, instituut Beleid \& Management Gezondheidszorg (iBMG), Erasmus Universiteit Rotterdam (EUR)

\section{Samenvatting}

'Even Buurten' is een Rotterdams initiatief. Hierin proberen professionals uit zorg en welzijn via een integrale wijkaanpak de sociale netwerken rondom thuiswonende ouderen te verstevigen. Doel van dit sociale netwerk is (vroeg) signalering en het bieden van concrete hulp en ondersteuning aan kwetsbare ouderen. Uit onderzoek naar het 'Even Buurten'-initiatief komt het belang van een sterk sociaal buurtnetwerk duidelijk naar voren. Het succes van een integrale wijkaanpak hangt in sterke mate af van een integraal formeel én informeel ondersteunend netwerk in de buurt. Formele en informele netwerken werken echter nog niet goed samen. En ook binnen het formele netwerk (bijv. tussen zorg en welzijn) wordt nog onvoldoende samengewerkt om kwetsbare ouderen optimale ondersteuning te bieden. Deze klinische les beschrijft hoe integrale, wijkgerichte ondersteuning beter tegemoetkomt aan de behoeften en wensen van kwetsbare ouderen. 
Dames en heren,

Door de dubbele vergrijzing en roep om kostenbesparing in de zorg wordt steeds meer een appel gedaan op ondersteuning van ouderen door informele netwerken. ${ }^{1}$ De meeste ouderen willen zo lang mogelijk zelfstandig blijven wonen in hun eigen buurt. Naast familie en formele ondersteuning (vanuit zorg en welzijn) is ondersteuning van een sociaal netwerk in de buurt een belangrijke voorwaarde voor thuiswonende ouderen om dat doel te bereiken., ${ }^{2,3}$ Buurtondersteuning bestaat meestal uit instrumentele en emotionele ondersteuning en is daarmee complementair aan de ondersteuning vanuit formele netwerken. ${ }^{3-5}$ Naarmate ouderen zich beter ondersteund voelen in de buurt en er bijvoorbeeld sprake is van meer sociale cohesie in de buurt, zijn zij minder kwetsbaar. ${ }^{6}$ Daarnaast blijkt dat het sociale netwerk van ouderen en de sociale cohesie in de buurt bijdragen aan het welzijn ${ }^{7}$ en de gezondheid van ouderen. ${ }^{8-}$ 10

Op dit moment zijn er echter ouderen die met de huidige aanpak onvoldoende ondersteund worden, terwijl zij met wat extra ondersteuning in de buurt mogelijk wel langer zelfstandig zouden kunnen blijven wonen. Welzijns- en zorgprofessionals kunnen een belangrijke schakel zijn in het versterken van de sociale netwerken in een buurt. ${ }^{4,11}$ In Rotterdam is sinds mei 2011 het project 'Even Buurten' actief, waarin professionals uit zorg en welzijn via een integrale wijkaanpak proberen de sociale netwerken rondom thuiswonende ouderen te verstevigen. Doel van dit sociale netwerk is (vroeg)signalering en het bieden van concrete hulp en ondersteuning aan kwetsbare ouderen. ${ }^{12}$ Vaak gaat het bij deze ouderen om een combinatie van problemen, variërend van licht tot zwaar, waardoor zij als kwetsbaar worden beschouwd. ${ }^{13} \mathrm{Zij}$ kunnen met ondersteuning vanuit het (in)formele netwerk echter nog steeds goed functioneren en zelfstandig in hun eigen buurt blijven wonen. Deze kwetsbare ouderen worden door 'sleutelfiguren' gesignaleerd en doorverwezen naar een 'spil' van het 'Even Buurten'project. Deze spil bezoekt kwetsbare ouderen thuis en gezamenlijk met de ouderen verkennen zij welke problemen er spelen en worden mogelijke oplossingen geïnventariseerd, zoals geillustreerd in de volgende casus.

\section{Casus Mevrouw Prins}

Mevrouw Prins, 72 jaar oud, woont in een hoge flat in een buitenwijk van Rotterdam. Zij heeft nooit kinderen gehad en woont sinds het overlijden van haar man al tien jaar alleen. Mevrouw Prins werkte vroeger jarenlang met plezier als receptioniste bij een bank en is er trots op dat ze altijd zelfstandig is geweest. Tot haar verdriet heeft ze het werk door haar longaandoening COPD niet tot haar pensioen kunnen volhouden. Naast de impact die deze longziekte had op haar arbeidsleven, is haar sociale leven er ook op achteruitgegaan. Behalve persoonlijke begeleiding en huishoudelijke verzorging van de thuiszorg heeft mevrouw een goede buurman die een oogje in het zeil houdt. Hij merkt dat mevrouw nog maar nauwelijks buitenkomt en maakt zich steeds meer zorgen over haar. Bovendien vermoedt hij dat mevrouw gezien haar lichamelijke achteruitgang in aanmerking komt voor meer voorzieningen. Als hij dit aan haar voorlegt, zegt ze graag advies te willen krijgen over haar financiële situatie en mogelijke voorzieningen.

Via de bewonersvereniging komt de buurman in aanraking met Even Buurten. In overleg met de spil besluiten ze dat de spil een huisbezoek zal brengen aan mevrouw om te vragen hoe het met haar gaat en of zij verdere ondersteuning nodig heeft. In het gesprek met mevrouw blijkt dat zij niet zozeer behoefte heeft aan praktische ondersteuning of meer huishoudelijke of persoonlijke verzorging, zoals de buurman had ingeschat. 'Ik zit er warmpjes bij', vertelt mevrouw. Wel geeft mevrouw aan er veel moeite mee te hebben dat haar kringetje van kennissen en vrienden steeds kleiner wordt door sterfgevallen en verslechterde mobiliteit, en dat zij mensen in haar omgeving mist met wie ze kan praten over haar ziekte. Daarnaast wordt in het gesprek duidelijk dat mevrouw intens geniet van het buiten zijn, maar dat zij daarin erg wordt belemmerd door de zuurstoftank die ze draagt en haar angst om met de scootmobiel te rijden. Wanneer de spil aan haar vraagt wat haar zou kunnen helpen, geeft zij aan het fijn te vinden als 
iemand de komende tijd met haar wil oefenen met het rijden met de scootmobiel.

Na het gesprek gaat de spil op zoek naar iemand binnen het informele netwerk die mevrouw kan ondersteunen. Via een oproepje in de wijkkrant vindt de spil al snel een enthousiaste mevrouw, die dicht bij mevrouw Prins in de buurt blijkt te wonen. Wanneer de twee elkaar ontmoeten, is er meteen een heel goede klik. Momenteel bezoekt de buurvrouw mevrouw Prins elke week, waarbij ze geregeld samen een wandeling maken of boodschapjes doen. Ook wordt mevrouw Prins door deze buurvrouw ondersteund in het oefenen met de scootmobiel, zodat mevrouw Prins het ook niet meer zo eng vindt om alleen naar buiten te gaan.

\section{Beschouwing}

Uit de beschreven casus komt het belang van een sterk sociaal buurtnetwerk duidelijk naar voren. Allereerst wordt duidelijk dat buren een belangrijke signalerende functie hebben. Buurtbewoners onderscheiden zich van professionals door hun nabijheid en vertrouwdheid, ${ }^{14}$ wat hen goed in staat stelt vroegtijdig te signaleren. Hierdoor kan worden voorkomen dat, in dit geval mevrouw Prins, in een sociaal isolement raakt. Oudere buurtbewoners houden vaak een 'oogje in het zeil', mede omdat zij zich realiseren dat zij zelf het risico lopen op korte termijn kwetsbaar te worden en dan zelf ook graag goede ondersteuning willen ontvangen. Hoewel de buurman van mevrouw Prins aanvoelt dat het niet goed met haar gaat, weet hij tegelijkertijd niet goed hoe hij hiermee moet omgaan. Door de beschikbaarheid van een aanspreekpunt in de buurt, in dit geval de spil van Even Buurten, kan hij met zijn zorgen terecht bij een professional. Hiervoor is een vertrouwensband tussen de spil en het informele netwerk nodig.

Wanneer deze professional in gesprek gaat met mevrouw, blijkt dat de buurman zich terecht zorgen maakte. De aard van de problematiek blijkt wel anders te liggen dan de buurman dacht. Door de vraaggerichte manier van werken van de spil van Even Buurten wordt de daadwerkelijke hulpvraag van mevrouw duidelijk: de behoefte aan een groter sociaal netwerk waaraan zij steun kan ontlenen (in tegenstelling tot de - voor de buurman - ogenschijnlijke zorgvraag). Het succes van Even Buurten en gelijksoortige initiatieven is daarmee sterk afhankelijk van een integraal formeel én informeel ondersteunend netwerk in de buurt, waarbij partners op het gebied van preventie, cure, care, welzijn en wonen goed met elkaar samenwerken, van signalering tot zorgverlening. ${ }^{15,16}$

Helaas blijkt de zo noodzakelijke samenwerking binnen het formele en tussen het formele en informele netwerk nog onvoldoende van de grond te komen. Vorig jaar zijn interviews afgenomen onder actieve buurtbewoners en professionals om na te gaan welke vorm de samenwerking aanneemt en wat hierin mogelijke belemmeringen zijn voor goede samenwerking. ${ }^{4}$ Hoewel professionals het belang van het informele netwerk rondom ouderen onderschrijven, zijn zij tegelijkertijd terughoudend om dit netwerk bij de ondersteuning van kwetsbare ouderen te betrekken. Formele en informele ondersteuners lijken in gescheiden werelden te leven; er is vrijwel geen samenwerking gevonden. Naast het ontbreken van samenwerking tussen het informele en formele netwerk, kwam in het onderzoek ook duidelijk naar voren dat de samenwerking tussen professionals van verschillende organisaties niet vanzelfsprekend is (zoals tussen zorg en welzijn). Hoewel professionals erg veel waarde hechten aan de behoeften en het welzijn van de cliënt, geven zij tegelijkertijd aan dat de (financiële) belangen van de organisatie samenwerking in de weg staan. De focus op het verhogen van productie en inkomsten van de organisatie waarin professionals werkzaam zijn, maakt dat deze organisaties zich vaak op dezelfde klanten richten. Hierdoor ontstaat het gevoel dat men in dezelfde vijver vist. Een adjunctdirecteur van een welzijnsorganisatie licht toe dat in deze periode van schaarste partijen 'vooraan willen lopen' en minder kritisch zijn over welke doelgroep en hulpvraag passen bij hun expertise. Een multidisciplinair team uit zorg en welzijn kan ervoor zorgen dat wel alle benodigde expertise wordt ingezet.

Even Buurten en gelijksoortige initiatieven in de wijk kunnen bijdragen aan het wegnemen van concurrentiegevoelens tussen organisa- 
ties doordat financiële schotten worden weggenomen. Dit stimuleert professionals over de muren van hun organisaties en sectoren heen te kijken en samenwerking te zoeken met andere professionals. Naast samenwerking binnen het formele circuit is samenwerking noodzakelijk tussen het formele en informele netwerk. Uit de literatuur komt duidelijk naar voren dat informele en formele zorgverlening complementair zijn aan elkaar en dat er nauwelijks sprake is van onderlinge substitutie. Daarnaast blijkt samenwerking tussen informele en formele zorg bij uitstek van belang te zijn in de ondersteuning van kwetsbare ouderen. ${ }^{17}$ Formele zorgverleners kunnen kwetsbare ouderen vragen naar hun informele ondersteuners en hen als partner bij het zorgverleningsproces betrekken. Op deze manier kan beter tegemoetgekomen worden aan de behoeften en wensen van kwetsbare ouderen en wordt integrale, wijkgerichte ondersteuning geboden.

\section{Leerpunten}

- Door de dubbele vergrijzing en roep om kostenbesparing in de zorg wordt steeds meer een appel gedaan op ondersteuning van ouderen door informele netwerken.

- Informele ondersteuning in de buurt is een belangrijk onderdeel van het sociale netwerk van kwetsbare ouderen.

- Buurtondersteuning bestaat meestal uit instrumentele, sociale en emotionele ondersteuning en is daarmee complementair aan de ondersteuning vanuit formele netwerken.

- Formele en informele netwerken werken nog niet goed samen. Maar ook binnen het formele netwerk (bijvoorbeeld tussen zorg en welzijn) wordt nog onvoldoende samengewerkt om kwetsbare ouderen optimaal te ondersteunen.

- Professionals kijken nog vaak te veel vanuit hun eigen organisatie en houden te weinig rekening met de behoefte van kwetsbare ouderen aan een ondersteunend netwerk dat optimale, integrale ondersteuning biedt.

- Professionals moeten over de muren van de eigen organisatie en andere sectoren heenkijken en samenwerking zoeken met zowel andere professionals als informele ondersteuners om de behoeften en ondersteu- ningsvragen van kwetsbare ouderen centraal te stellen.

\section{Dankwoord}

Deze klinische les is gebaseerd op de resultaten van de evaluatie van Even Buurten door de Erasmus Universiteit Rotterdam, en is gefinancierd door ZonMw (projectnummer 314030201). Graag bedanken wij Natasja Sterk (spil van Even Buurten) voor de casusbeschrijving.

\section{Literatuur}

1 Penning MJ, Keating NC. Self-, informal and formal care: partnerships in community-based and residential long-term care settings. Can J Aging 2000;19:75-100.

2 Barker JC. Neighbours, friends, and other nonkin caregivers of community-living dependent elders. J Gerontol 2002;57b:158-67.

3 Shaw BA. Anticipated support from neighbours and physical functioning during later life. Research on Aging 2005;27:503-25.

4 Dijk HM van, Cramm JM, Nieboer AP. The experiences of neighbour, volunteer and professional support-givers in supporting community-dwelling older people. Health Soc Care Community doi: 10.1111/hsc.12006.

5 Gardner PJ. Natural neighborhood networks Important social networks in the lives of older adults aging in place. J Aging Studies 2011;25: 263-71.

6 Cramm JM, Nieboer AP. Relationships between frailty, neighbourhood security, social cohesion and sense of belonging among community-dwelling older people. Geriatr Gerontol Int 2012 doi: 10.1111/j.1447-0594.2012.00967.x.

7 Cramm JM, Dijk HM van, Nieboer AP. The importance of perceived neighborhood social cohesion and social capital for the well-being of older adults in the community. Gerontologist 2012 doi:10.1093/geront/gnso52.

8 Hortulanus R, Machielse A, Meeuwesen L. Sociaal isolement: Een studie naar sociale contacten en sociaal isolement in Nederland. 's-Gravenhage: Elsevier Overheid/ Read Business, 2003.

9 Stephens C, Alpass F, Towers A, Stevenson B. The effects of types of social networks, perceived social support, and loneliness on the health of older people: accounting for the social context. J Aging and Health 2011;23:887-911.

10 Berkman LF, Glass T, Brissette I, Seeman TE. 
From social integration to health: Durkheim in the new millennium. Social Science \& Medicine 2000;51:843-57.

11 Cramm JM, Hoeijmakers M, Nieboer AP. Relational coordination between community health nurses and other professionals in delivering care to community-dwelling frail people. J Nursing Managem (in press).

12 Cramm JM, Dijk HM van, Lötters F, Exel J van, Nieboer AP. Research protocol integrated neighborhood approach. BMC Res Notes 2011;4:532.

13 Gobbens RJJ, Assen MALM van, Luijkx KG, Wijnen-Sponselee MTh, Schols JMGA. The Tilburg
Frailty Indicator: Psychometric Properties. J Am Med Dir Assoc 2011;11:344-54.

14 Nocon A, Pearson M. The roles of friends and neighbours in providing support for older people. Ageing and Society 2000;20:341-67.

15 Fast J, Keating N, Otfinowski P, Derksen L. Characteristics of family/friend care networks of frail seniors. Canad J Aging 2004;23:5-19.

16 Litwak E. Helping the elderly: the complementary roles of informal networks and formal systems. New York: Guilford Press, 1985.

17 Litwak E, Attias-Donfut C. The inter-relationship between formal and informal care: a study in France and Israel. Ageing Soc 2009;29(1):71-91. 